\title{
Reinventing the Model of Pesantren-Based Literary with the Insight of Religious Moderation
}

\author{
Moh. Andi Hakim \\ IAIN Syekh Nurjati Cirebon \\ andihakim@syekhnurjati.ac.id
}

\begin{abstract}
This study revealed the design of the model of pesantren-based literary with the insight of religious moderation and its contribution in strengthening religious moderation through education and writing training programs. Establishing literacy model of santri with a good scientific tradition and contextual dialectic of thought is must be developed. Through the model developed as an effort to reinvent literature of pesantren with religious moderation values is able to become a reference for the design of santri writing training and its application in realizing Wasatiyyah Islam. This research is qualitative method with descriptive qualitative approach. The data are collected through observation and documentation. The results of this study found two important things; First, the new model of pesantren-based literary with the insight of religious. Second, the contribution of pesantren-based literary model in realizing the agent of peace.
\end{abstract}

Keywords: Moderation, Pesantren, Wasatiyyah

\section{Introduction}

After the issuance of Undang-Undang Nomor 18 tahun 2021 (Indonesia Regulation of Pesantren), there was a change in the perception of all Indonesian people about pesantren which had been marginalized as part of formal education in Indonesia. The presence of the law, returns the position of pesantren to its essential goals, which not only has an educational function, but also in preaching community empowerment as part of the original function of pesantren (Mubarok, 2021).

Currently, pesantren have entered a phase of cultural absurdity, as predicted by Marshal McLuhan, a communication expert in his writing Understanding Media: Extension of A Man. He stated that the development of media flow was an excess of the emergence of the global village. This is marked by the erosion of locus identities of cultural identity barriers. Geographical boundaries and cultural identity are also increasingly absurd considering that the global village community does not recognize geographic boundaries because inter-regions are connected with communication and media. 
While on the other hand, our formal education is still experiencing serious problems. A number of studies confirm that the attitude of tolerance and respect for the diversity, including minority and marginal groups, our educational actors is still weak (PPIM, 2017, 2018; Wahid Institute, 2019). In our higher education, a number of studies show the spread of extremism among universities (Setara Institute, 2019); the phenomenon of exclusivism in religious education textbooks among public universities (PPIM, 2018); Muslim student activists have exclusive religious understandings (CSRC, 2017); religious activities in the university environment encourage the growth of exclusive religious views (CISForm, 2018); infiltration of radicalism and extremism in the university environment through campus mosques (INFID, 2018); and 39\% of students in 7 state universities are exposed to radicalism (BNPT, 2018). ${ }^{1}$

Umam, (2010) in his research explained that the guidance efforts carried out in the deradicalization process were not enough with formal education, but there needed to be preventive efforts by avoiding the younger generation from extremist and terrorist groups. In addition, through multicultural education, Arifin also conveyed in his research that it became a central intsrument in the deradicalization process (Arifin, 2014).

This has actually been responded quickly by the Ministry of Religious Affairs through its priority program, namely Mainstreaming religious moderation. Religious moderation is a primary program and become the tagline was initiated by Ministry of Religious Affairs. 2019 was declared as the year of religious moderation, the Ministry is truely focus on promoting a moderate religious way, neither radical nor liberal. This is an answer regarding the moderation of religion, because Islam is actually a moderate religion (Wasatiyyah).

A study on counter-radicalism education was conducted by Machali, (2013) through the concept of peace education that is able to develop attitudes and behavior in guiding live with mutual respect, tolerance, peace, mutual help, and antiviolence. Temporary, Miswari (2013) synthesizes that the wave of radicalism can also be dammed through multicultural awareness that stems from the values of Bhineka Tunggal Ika. How the philosophy of the Indonesian nation is so full of

\footnotetext{
${ }^{1}$ Excerpted from the presentation at the launch of the results of the Diversity survey at the Ivory Tower: Religious Tolerance in Higher Education by PPIM UIN Syarif Hidayatullah Jakarta, Monday 1 March 2021
} 
providing an understanding of efforts to build a tolerant and the spirit of unity in diversity.

The significance of this research is in its usefulness, both for researchers and related institutions. This research formulated the new models of writing training with the perspective of religious moderation in an effort to counter radicalism narratives. The concept that comes from the values of pesantren local wisdom, religious moderation and nationality becomes a model for preserving the literary tradition of pesantren with an insight into religious moderation. In addition, this research can be a reference material or source for other researchers who are concerned in the discourse of pesantren literature and strengthening religious moderation in pesantren.

This study uses a qualitative descriptive approach to find an overview of the pesantren literary model with religious moderation values. As described by (Sukmadinata, 2007) that descriptive research is a research method used to describe existing phenomena, both presently and in the past.. Donald explained that qualitative research aims to describe and clarify human experiences in their lives (Judge, 2014). This became the basis of thought to find the ideal concept of pesantren literary guidance with religious moderation values. Through literature analysis, the author collects various information related to the theory of pesantren literature and religious moderation. The purpose of this research is to reveal how the design and contribution of pesantren literature in strengthening religious moderation.

\section{Results and Discussion}

Modeling of pesantren literature can be done through education and writing training programs for students or santri. There are several stages of training and materials provided in the program, including: 1) Basic Materials 2) Writing Skills Materials 3) Writing Practice Materials, and 4) Assessment and Evaluation.

\section{A. Basic Material}

The basic material is the main thing that must be given to students, in relation to the essence of writing, understanding the concept of religious moderation and the syarah of Pancasila. Some of the main things taught in the pesantren literature education and training program with an insight into religious moderation include the following: 
Table 1. Basic Material

\begin{tabular}{|c|c|c|c|}
\hline NO & Material & Focus and Scope & Information \\
\hline 1 & $\begin{array}{l}\text { Tirakat Becomes an } \\
\text { Indigenous } \\
\text { (Indigenous writer who has } \\
\text { Islamic and Indonesian } \\
\text { insights) }\end{array}$ & $\begin{array}{l}\text { 1. Provide an understanding of the } \\
\text { essence and indigenous writers } \\
\text { 2. Provide an understanding of the } \\
\text { benefits and advantages of being a } \\
\text { writer } \\
\text { 3. Provide motivation and } \\
\text { encouragement for students to } \\
\text { become writers } \\
\text { Tips for being productive and } \\
\text { creative students }\end{array}$ & Basic Material \\
\hline 2 & 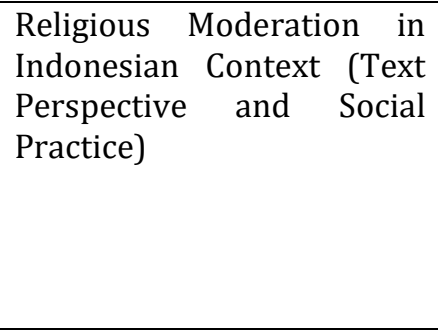 & $\begin{array}{l}\text { 1. } \begin{array}{l}\text { Definition, goals and concepts of } \\
\text { religious moderation }\end{array} \\
\text { 2. Religious moderation in the } \\
\text { perspective of religious holy texts } \\
\text { 3. Religious moderation in the } \\
\text { Indonesian context } \\
\text { 4. } \begin{array}{l}\text { Moderation of religion in the } \\
\text { context of student affairs }\end{array}\end{array}$ & Basic Material \\
\hline 3 & $\begin{array}{l}\text { Syarah Pancasila, Islam and } \\
\text { Indonesianness }\end{array}$ & $\begin{array}{l}\text { 1. The content and philosophy of } \\
\text { Pancasila as the basis of the state } \\
\text { 2. The process of achieving national } \\
\text { consensus } \\
\text { 3. The dynamics of Pancasila and } \\
\text { Islam as the basis of the state }\end{array}$ & Basic Material \\
\hline
\end{tabular}

Referring to the materials above, it actually emphasizes the role of pesantren that are able to integrate Islamic and Indonesian ideas. As formulated by Nurcholish Madjid responded to the context of Indonesian history in 1970. Theologically, this thought was born because of the emergence of religious fundamentalism and various kinds of exclusive influences.(Ridwan, 2002). According to him, as the majority, Indonesian Muslims need to realize the importance of awareness of pluralism and inclusivism (Madjid, 2009).

Nurcholish Madjid's criticism of fundamentalism is aimed at the process of stigmatizing some Muslims who encourage the establishment of Islamic law in Indonesia. Nurcholish Madjid's inclusive thinking can be studied from, firstly, regarding the moderate and substantive Islamic spirit. Secondly, the Indonesian multicultural spirit emerged as a balance against formal-exclusive religious understandings that had the potential to become embryos and trigger for horizontal conflicts at that time.

Zamakhsyari Dhofier (1994) explained that pesantren as indigenous and oldest Islamic educational institutions in Indonesia have been able to contribute to the nation's struggle, in addition to the educational function. In fact, its 
presence existed before Indonesia's independence. The Dutch government released in 1831 the number of Islamic institutions such as pesantren reached 1,853. Historically, pesantren have been the only educational institutions belonging to indigenous peoples that have made a very large contribution in shaping a literate society (social literacy) and cultural literacy (Qomar, nd).

\section{B. Writing Skills Material}

In addition to the basic material that must be provided in the education and training program for writing the pesantren literature with a view of religious moderation, there is a material for writing skills. Santri are expected to be able to master the skills in expressing their ideas through writing. Through researchbased and non-research-based popular writing. Some of the materials that can be developed are as follows:

Table 2. Writing Skill Material

\begin{tabular}{|c|c|c|c|}
\hline No & Material & Focus and Scope & Information \\
\hline 1 & $\begin{array}{l}\text { Understanding Popular } \\
\text { Writing (Short Stories, } \\
\text { Poetry and Features) / } \\
\text { Santri and Online } \\
\text { Journalism Practices }\end{array}$ & $\begin{array}{l}\text { a. Provide understanding to students } \\
\text { about short stories, poetry and features } \\
\text { b. Provide understanding to students } \\
\text { about student journalism and online } \\
\text { discourse } \\
\text { c. Provide understanding to students } \\
\text { about the stages of writing } \\
\text { d. Intensive practice of writing short } \\
\text { stories, poetry and features }\end{array}$ & $\begin{array}{l}\text { Writing Skills } \\
\text { Material }\end{array}$ \\
\hline 2 & $\begin{array}{l}\text { Selection of topics and } \\
\text { problems, limiting } \\
\text { topics, determining the } \\
\text { title of literary works }\end{array}$ & $\begin{array}{l}\text { a. Provide understanding and } \\
\text { identification of problems and topics in } \\
\text { writing } \\
\text { b. Selecting and making an inventory of } \\
\text { potential problems in students' lives } \\
\text { and their social environment } \\
\text { c. Selecting the title and segmentation of } \\
\text { the essay }\end{array}$ & $\begin{array}{l}\text { Writing Skills } \\
\text { Material }\end{array}$ \\
\hline 3 & $\begin{array}{l}\text { Making a literary } \\
\text { framework }\end{array}$ & $\begin{array}{l}\text { a. Manage problems and map them } \\
\text { through conceptual charts } \\
\text { b. Make outlines and angles in formulating } \\
\text { a writing framework } \\
\text { c. Develop a cycle and plan the stages of } \\
\text { writing } \\
\text { d.Individually present the results of the } \\
\text { writing framework }\end{array}$ & $\begin{array}{l}\text { Writing Skills } \\
\text { Material }\end{array}$ \\
\hline 4 & $\begin{array}{l}\text { Good/Correct Language } \\
\text { and Spelling in Writing }\end{array}$ & $\begin{array}{l}\text { a. Provide an understanding of the use of } \\
\text { language and spelling in accordance } \\
\text { with the rules of writing } \\
\text { b. Using a variety of language in } \\
\text { accordance with the rules of writing } \\
\text { c. Use spelling that is in accordance with } \\
\text { the rules of writing } \\
\text { d.Santri and trainers conduct linguistic } \\
\text { analysis on the writings that have been } \\
\text { made }\end{array}$ & $\begin{array}{l}\text { Writing Skills } \\
\text { Material }\end{array}$ \\
\hline
\end{tabular}


The above materials are directed at understanding writing theory and its relation to the significance of mainstreaming religious moderation. Through writing competencies developed, santri are able to mix peaceful content and information that is based on at least three reasons. First, the presence of religion to maintain human dignity with the main message of rahmah (love). Second, religious thought its historical views, while reality continues to move dynamically. Third, the Republic of Indonesia must be maintained through a cultural strategy.

Facts related to religious ways that tend to be radical and extreme can threaten the reasoning and attitudes of the younger generation, including santri. Therefore, it is necessary to formulate a student writing training program that focuses on positioning students as producers of counter extremist writing content. This can be done through education, guidance and assistance in good writing skills for santri.

Religion in humans live grow throughout the history of their existence on earth, religion is also present based on very human needs, at least in terms of human emotions themselves (Azra, 1996). Because of its nature which is in line with human nature, religion is then believed and used as the basis of worldview, because religion in its sacred position is considered as God's blueprint which is formulated to be further used as a reference to solve all life's problems (Shihab, 1998).

Wach, (1948) Explaining that religion as a universal value system, has appeal and is very interesting to offer to humans, as Joachim Wach said, he sees religion as having three forms in expressing its universal values, namely, belief systems (theoretical disclosures that manifest as belief system), the system of worshif (as a worship system), the system of social relations (as a public relations system). At the level of religious values, religion has five dimensions, including: the dimension of ideology (belief system), the dimension of religious practice (practice), the dimension of experience (feeling), the dimension of knowledge (knowledge) and the dimension of religious consequences (effect) (Robertson, 1992). 


\section{Writing Practice}

After the students get the basic material and writing material, then they are directed to writing practice activities. The practice of writing is carried out to actualize the knowledge and understanding of students regarding religious moderation. The preparation of religious moderation content can be facilitated through the following materials:

Table 3. Writing Practice

\begin{tabular}{|c|c|c|c|}
\hline No & Material & Focus and Scope & Information \\
\hline 1 & $\begin{array}{l}\text { Religious Moderation } \\
\text { Content Writing Tips }\end{array}$ & $\begin{array}{l}\text { a. Provide an understanding of the } \\
\text { methods, techniques and stages of } \\
\text { writing a book } \\
\text { b. Practice Mind Maps and write Book } \\
\text { content through group discussions } \\
\text { c. Evaluation and presentation of } \\
\text { group discussion results }\end{array}$ & Practice Material \\
\hline 2 & $\begin{array}{l}\text { Data collection, concept } \\
\text { generation, editing, typing } \\
\text { and book writing } \\
\text { systematics }\end{array}$ & $\begin{array}{l}\text { a. Collect references from various } \\
\text { scientific sources (Books, Journals, } \\
\text { Articles and academic manuscripts) } \\
\text { b. Inventory of primary and secondary } \\
\text { data related to the topic of writing } \\
\text { c. Complete the outline with } \\
\text { references that support and } \\
\text { complete the study of writing } \\
\text { d. Develop a systematic design of book } \\
\text { writing according to genre and } \\
\text { theme }\end{array}$ & Practice Material \\
\hline
\end{tabular}

The practice of santri writing must be linked to a good understanding of the context of religious moderation. An understanding of the authentic character of pesantren in the early days that was able to display a tolerant and peaceful face must be well narrated. In rural areas of Java, Sumatra, and Kalimantan, for example, there are many pesantren that have succeeded in conducting dialogue with the culture of the local community. Pesantrens in Java, especially those of the Syafi'i school, are able to be accommodative to local culture, so that the assimilation of pesantren with the community takes place well. The success of this kind of pesantren then becomes a tolerant religious model among Muslims in general. No wonder the character of Islam in Indonesia is often perceived as a friendly and peaceful Muslim (Katsir, 2010).

The pesantren education system and tradition give birth to values that are in line with the culture of peace. System Pesantren education requires students to be consistent and committed to the teachings of their religion on the one hand, but still inclusive. On the one hand, keep pesantren tradition, but on the other 
hand still respect the traditions outside boarding school. Pesantrens on the one hand require their students to remain consistent in worship and da'wah, but on the other hand, students must promote tasamuh (tolerant) and respect local culture (local wisdom) and diversity of the surrounding community (Darmoko, 2015).

\section{Evaluation and Assessment}

The final stage of the literary writing education and training program for pesantren with religious moderation is assessment and evaluation. Students who have been able to understand the basic material and skills, and practice for the next writing will receive an evaluation and assessment from the supervisor. This assessment is carried out to direct the students in the process of publishing their work. Some of the materials provided include:

Table 4. Evaluation and Assesment

\begin{tabular}{|c|c|c|c|}
\hline No & Material & Focus and Scope & Information \\
\hline 1 & $\begin{array}{lr}\text { Peerediting } & \text { Student } \\
\text { Religious } & \text { Moderation } \\
\text { Content Writing }\end{array}$ & $\begin{array}{l}\text { a. Santri and trainers conduct an } \\
\text { analysis of the work of students } \\
\text { b. Perform intensive editing of the } \\
\text { work of students } \\
\text { c. Editing is done in terms of language } \\
\text { and writing rules according to the } \\
\text { correct rules } \\
\text { d. Make notes of improvements to the } \\
\text { results of writing }\end{array}$ & $\begin{array}{l}\text { Pre Monitoring, } \\
\text { Editing and } \\
\text { Evaluation }\end{array}$ \\
\hline 2 & $\begin{array}{l}\text { Revising the Writing } \\
\text { Results of Religious } \\
\text { Moderation for Santri in } \\
\text { the form of an anthology } \\
\text { article/book }\end{array}$ & $\begin{array}{l}\text { a. Santri and trainer revise mistakes in } \\
\text { writing after editing } \\
\text { b. Correcting errors based on repair } \\
\text { notes } \\
\text { c. Students and trainers discuss to } \\
\text { reduce errors in writing }\end{array}$ & $\begin{array}{l}\text { Peer Monitoring, } \\
\text { Editing and } \\
\text { Evaluation }\end{array}$ \\
\hline 3 & $\begin{array}{l}\text { Evaluation and Analysis of } \\
\text { Santri's Religious } \\
\text { Moderation Content }\end{array}$ & $\begin{array}{l}\text { a. Santri and trainer analyze the } \\
\text { content of the work that has been } \\
\text { made } \\
\text { b. Directing and deepening the } \\
\text { contents of students' writings } \\
\text { c. Sharpen the strengths and erode the } \\
\text { shortcomings in the work of students } \\
\text { d. Santri and trainers correct } \\
\text { deficiencies and errors in writing, } \\
\text { especially regarding the contents of } \\
\text { the book }\end{array}$ & $\begin{array}{l}\text { Pre Monitoring, } \\
\text { Editing and } \\
\text { Evaluation }\end{array}$ \\
\hline 4 & $\begin{array}{l}\text { Postediting Writing Islamic } \\
\text { Moderation Content for } \\
\text { Santri in the form of } \\
\text { anthology articles/books }\end{array}$ & $\begin{array}{l}\text { a. Santri and trainers conduct an } \\
\text { analysis of the work of students } \\
\text { b. Perform intensive editing of the } \\
\text { work of students } \\
\text { c. Editing is done in terms of language } \\
\text { and writing rules according to the } \\
\text { correct rules } \\
\text { d. Make notes of improvements to the } \\
\text { results of writing }\end{array}$ & $\begin{array}{l}\text { Post Monitoring, } \\
\text { Editing and } \\
\text { Evaluation }\end{array}$ \\
\hline
\end{tabular}




\begin{tabular}{|c|c|c|c|}
\hline 5 & $\begin{array}{l}\text { Final Revision of the } \\
\text { Results of } \quad \text { Writing } \\
\text { Moderate Religious } \\
\text { Content for Students }\end{array}$ & $\begin{array}{l}\text { a. Santri and trainer analyze the } \\
\text { content of the work that has been } \\
\text { made } \\
\text { b. Directing and deepening the } \\
\text { contents of students' writings } \\
\text { c. Sharpen the strengths and erode the } \\
\text { shortcomings in the work of students } \\
\text { d. Santri and trainers correct } \\
\text { deficiencies and errors in writing, } \\
\text { especially regarding the contents of } \\
\text { the book }\end{array}$ & $\begin{array}{l}\text { Post Monitoring, } \\
\text { Editing and } \\
\text { Evaluation }\end{array}$ \\
\hline 6 & $\begin{array}{l}\text { Finalization of Santri's } \\
\text { Work in the form of } \\
\text { articles/books }\end{array}$ & $\begin{array}{l}\text { a. Santri and trainer check and re- } \\
\text { check the work of the book that has } \\
\text { been written } \\
\text { b. Final review and analysis of book } \\
\text { content and writing }\end{array}$ & $\begin{array}{l}\text { Post Monitoring, } \\
\text { Editing and } \\
\text { Evaluation }\end{array}$ \\
\hline 7 & $\begin{array}{l}\text { Evaluation of Performance } \\
\text { and Quality of Santri's } \\
\text { Religious Moderation } \\
\text { Content in the form of } \\
\text { articles/books }\end{array}$ & $\begin{array}{l}\text { a. Together to evaluate the results of } \\
\text { the books that have been made } \\
\text { b. Together to evaluate the interests } \\
\text { and advantages of students } \\
\text { c. Together to evaluate the brilliant } \\
\text { potentials of the institution }\end{array}$ & Finalization \\
\hline 8 & Soft Lauching by Santri & $\begin{array}{l}\text { a. Students present their work } \\
\text { b. Schools, directors and board of } \\
\text { Asatid conduct analysis and } \\
\text { evaluation } \\
\text { c. Reward and appreciation for the } \\
\text { work of students }\end{array}$ & Finalization \\
\hline 9 & $\begin{array}{l}\text { Publication and Branding } \\
\text { of Santri's Works }\end{array}$ & $\begin{array}{l}\text { a. Provide an understanding of the } \\
\text { publication and branding of } \\
\text { students' works } \\
\text { b. Carry out massive and effective } \\
\text { publication of the work of students } \\
\text { c. The contestation and participation of } \\
\text { students in various writing } \\
\text { competitions }\end{array}$ & Finalization \\
\hline
\end{tabular}

\section{Conclusion}

Through the model designed for students, it is intended that students are able to write various types of writings with an insight into religious moderation. This ability is then expected to become one of the life skills possessed by students, including skills as professional writers. Modeling of pesantren literature can be done through education and writing training programs for santri. There are several stages of training and materials provided in the program, including: 1) Basic Materials 2) Writing Skills Materials 3) Writing Practice Materials, and 4) Assessment and Evaluation. This program is at least based on the goal of realizing Islam that is Rahmatan Lil Alamin. Pesantren will produce the ambassadors of religious moderation. 
Reinventing the Model of Pesantren-Based Literary...

\section{Bibliography}

Arifin, S. (2014). Membendung Arus Radikalisasi Di Indonesia. Islamica, 8(4).

Azra, A. (1996). Pergolakan politik Islam: dari fundamentalisme, modernisme, hingga postmodernisme. Paramadina.

Darmoko, M. R. dan P. D. (2015). Pendidikan Pesantren dan Nilai Budaya Damai. Madaniyah, 8, 132.

Dhofier, Z. (1994). Tradisi Pesantren: Studi tentang Pandangan Hidup Kyai. LP3ES.

Hakim, M. A. (2014). The Analysis of MAK Halliday's Theory of Systemic Functional Grammar and Its impact to Discourse Analysis and Genre Based Approach. Vision, 2.

Katsir, A. M. dan I. (2010). Pola Pendidikan Keagamaan Pesantren dan Radikalisme: Studi Kasus Pesantren-pesantren di Provinsi Jambi. Kontekstualita, 25(2), 257.

Machali, I. (2013). Peace Education dan Deradikalisasi Agama. Pendidikan Islam, $2(1)$.

Madjid, N. (2009). Cendekiawan dan Religiusitas Masyarakat. Paramadina.

Miswari, Z. (2013). Kesadaran Multikultural Dan Deradikalisasi Pendidikan Islam: Pengalaman Bhinneka Tunggal Ika Dan Qabul Al-Akhar. Pendidikan Islam, 2(1).

Qomar, M. (n.d.). Pesantren: Dari Transformasi Metodologi Menuju Demokratisasi Institusi. Erlangga.

Ridwan, D. (2002). Gagasan Nurcholis Madjid, Neo Modernisme Islam dalam Wacana Tempo dan Kekuasaan. Belukar Budaya.

Robertson, R. (1992). Agama Dalam Analisa dan Interpretasi Sosiologis. CV Rajawali.

Shihab, Q. (1998). Membumikan Al-Qur'an: Fungsi dan Peran Wahyu Dalam Kehidupan Masyarakat. Mizan.

Umam, S. (2010). Radical Muslims in Indonesia. Departmen of History. University of Hawaii.

Wach, J. (1948). Sociology of Religion. The university of Chicago Press. 